\title{
A Rethinking of the EFL Teachers’ Practical Knowledge*
}

\author{
JIANG Yu-hong, LI Qian, DENG Xiao-fang, WEI Jing \\ Southwest University, Chongqing, China
}

\begin{abstract}
This paper is a review of the research of TPK (teachers' practical knowledge) throughout the three decades. Up to now, TPK has already been regarded as one of the central themes within the field of language teacher education. However, a substantial number of problems concerning TPK are still controversial among the scholars. In this study we reexamine how to define TPK, what components TPK consists of, what the nature of TPK is, and how to access TPK. And then we discuss how the notion of TPK is used and analyzed in two lines of research. We intend to generate new sights into the knowledge that teachers hold to inform practices in daily teaching situations. At the same time, we are more interested in perceiving these issues from the perspective of teachers teaching English as a foreign language, teacher education, and professional development in China.
\end{abstract}

Keywords: TPK (teachers’ practical knowledge), components of TPK, nature of TPK, EFL (English as a foreign language) teachers in China, rethinking

\section{Introduction}

TPK (teachers' practical knowledge) is one of the central themes within the field of language teacher education. In the past three decades, though developments on the research of TPK have been made, a substantial number of problems concerning TPK are still controversial among the scholars. In order to generate new sights into the research of TPK, we review the background of the research and reexamine the definition of TPK, components of TPK, nature of TPK, and the ways to elicit TPK. And then we discuss how the notion of TPK is used and analyze it in two lines of research.

\section{Background of the Research}

Through three quarters of the 20th century, teacher education views teachers as passive technicians, which can be partly traced back to the behaviorism. What teachers are expected to know and what qualities teaching practices consist of are specified by the managerial hierarchy, namely ministry of education, teaching organizations, regulatory bodies and school principles (Leung, 2009). Teachers learn a battery of content knowledge and methodological knowledge and pass it on to successive generations of students. They apply the

\footnotetext{
* This paper is one of the research results of the project “A Study of English as Foreign Language Teachers' Professional Development in Universities in the West of China” which is sponsored by 2009 China National Social Sciences Research Foundation (Grant No. BFA090027), and is also supported by "the Fundamental Research Funds for the Central Universities" (Grant No. SWU1209306).

JIANG Yu-hong, professor, School of Foreign Languages, Southwest University.

LI Qian, teacher, Yucai College, Southwest University.

DENG Xiao-fang, associate professor, School of Foreign Languages, Southwest University.

WEI Jing, lecturer, School of Foreign Languages, Southwest University.
} 
supposed effective methods without taking into account of a host of differences in learners, programs, curricula, materials, policies, and the social-cultural environment that they are likely to encounter in their daily teaching (Ghaith \& Yaghi, 1997). This top-down approach becomes the target of criticism in 1980s (Wallace \& Louden, 1992). Gradually, there is a growing sense that there is little congruence between the theoretical knowledge teachers are taught and what teachers do in the classroom (Kagan, 1990; Bartels, 2005). Instead of blaming teachers for the relative lack of success of many curriculum reform efforts, scholars began to deem the teacher as the most influential factor in educational change (Duffee \& Aikenhead, 1992). And the research on teaching has increasingly focused on the knowledge generated by teachers which is highly personal and contextual (Shulman, 1987; Carter, 1990; Calderhead, 1990, 1996; Johnson, 1999; Richards \& Lockhart, 1996; Richardson, 1996). It is around this time that there flourishes a large number of terms, such as "personal knowledge" (Connelly \& Clandinin, 1985), "personal construct” (Olson, 1981), “principles” (Munby, 1983), “maxims” (Richards, 1996), “situated knowledge” (Leinhardt, 1988), "personal theories” (Sendan \& Roberts, 1998), “craft knowledge” (Meijer, 2010), and TPK (Elbaz, 1983, 1997; Tsang, 2004; Kettle \& Sellars, 1996; Black \& Hailliwel, 2000). These terms, as Clandinin and Connelly (1987) said, are simply different words naming the same thing given that the small subfield of research on teaching is relatively new. Researchers, in contrast to evaluating teaching with existing theories of traditional academic research, give the discourse power to teachers. On the basis of the teachers' personal understandings of teaching, frameworks of TPK, and corresponding implications are worked out. Studies of this kind intend to know what knowledge teachers bring to their work, how they construe their own teaching and what knowledge and beliefs influence what they do.

\section{The Definitions of TPK}

Literature review shows that there is a great deal of research (Elbaz, 1983; Clandinin \& Connelly, 1987; Meijer, Verloop, \& Beijaard, 1999) trying to define TPK. Most of the studies recognize that the cognition, or the knowledge and beliefs that underlie teachers' actions are TPK. This only summarizes parts of the characteristics of TPK.

To define TPK, three questions need to be asked. What constitutes TPK? Is it beliefs, values, interactive actions, or the enthusiasm a teacher shows? What is the existing form of TPK? When the dimension of time is taken into account, what should we focus on-past, present, or future? (CHEN, 2009a).

In order to better explain this term, discussion should be made in terms of teachers' preactive, interactive, and post-active activities.

In the first stage, teachers are in a reminiscent way talking about their beliefs, values, and principles they get from experiences as students, in professional preparation, or from a large quantity of daily teaching practices. Usually the existing forms of TPK in teachers during this period are stories, images, cases, or metaphors. Teachers have their ideas about their discipline, students, instruction, and self-images (Clandinin \& Connelly, 1987; Munby, 1983). Chinese scholars like JU (2003), D. LI (2005), and M. ZHANG (2008) explored on this level of TPK as well.

In the second stage, the preactive practical knowledge in stage one is stimulated by the class situation and becomes activated and is partly transformed into teachers' interactive actions and pathic knowledge (van Dreil, Beijarrd, \& Verloop, 2001). Teachers apperceive the space, the emotions of, and the subtle relationships between 
teachers and students, students and courses, and students and students. They have the wisdom of what to say and what to do in critical incidents, in the routine behaviors and habits. TPK during this period is expressed in the form of teachers' gestures, expressions in their eyes, lingual style, enthusiasm, artistic pause, and wisdom. All of them assist in the occurring of countless climax of class which is named "the essence of class" (CHEN, 2009b). In addition, contemporaneous reflection and immediate "reflective" awareness (van Manen, 2008) are common in the interactive practical knowledge. This enables teachers to reexamine their system of practical knowledge in class and also informs the post-active practical knowledge. In China, studies on this level of TPK are found in recent articles like JIANG and HAO (2010, 2011), Q. LI (2010), and L. ZHANG (2011).

In the last stage, teachers have ample time to reconsider their significant in-class incidents which finally enter into their corpus of practical knowledge in the first stage. These new messages will be used to guide their behaviors or be tested in practice to prove their effectiveness before they are fossilized into the belief system. To some extent, this step of reconstruction of TPK overlaps with the study of teachers' reflective teaching. Some researchers in China such as Q. LI, JIANG, and LENG (2013), L. LI and SUN (2010) probed this process.

Therefore, TPK is “in the teacher's past experience, in the teacher's present mind and body, and in the future plans and actions” (Connelly \& Clandinin, 1988, p. 25).

\section{The Components of TPK}

What are the components of TPK? This question is largely explored throughout these 30 years. However, there is no consensus among researchers. Some researchers discussed it from a theoretical perspective (Shulman, 1987); later, some scholars expanded and refined it on a philosophical level (CHEN, 2003; Meijer et al., 1999); some summarized from the out-of-class data of their studies (Elbaz, 1983); others claimed that knowing and action were not two separate things but one. The knowing was in the action itself. Therefore, they summed through the in-class exploration (Meijer, Verloop, \& Beijaard, 2002; Q. LI, 2010).

Shulman (1987) was one of the first to study the kinds of knowledge that teachers possess. These categories are: (1) content knowledge; (2) general pedagogical knowledge, with special reference to those broad principles and strategies of classroom management and organization that appear to transcend subject matter; (3) curriculum knowledge, with a particular emphasis on the materials and programs that serve as tools of the trade for teachers; (4) pedagogical content knowledge, that special amalgam of content and pedagogy that is uniquely the province of teachers, their own special form of professional understanding; (5) knowledge of learners and their characteristics; (6) knowledge of educational contexts, ranging from the workings of the group or classroom, the governance and financing of school districts, to the character of communities and cultures; and (7) knowledge of educational ends, purposes, and values, and their philosophical and historical grounds (Shulman, 1987, p. 8).

Another influential typology was made by CHEN (2003). She grouped TPK into six components after studying the literature at home and abroad. The six domains included teacher's educational belief, teacher's self-knowledge, impersonal knowledge, situational knowledge, strategic knowledge, and critical reflection.

Elbaz (1983) defined five categories of TPK: (1) knowledge of subject matter, which included not only knowledge of the subject discipline that the teacher was teaching but also theories related to learning; (2) knowledge of curriculum development, which referred to the structuring of learning experience and the 
curriculum content; (3) knowledge of instruction, which included classroom routines, classroom management, and student needs; (4) knowledge of self, which included knowledge of individual's characteristics such as one's own personality, age, attitudes, values and beliefs, as well as personal goals; and (5) knowledge of the milieu of schooling, which referred to the social structure of the school and its surrounding community.

The classification of Meijer et al. (1999) was: (1) subject matter; (2) students; (3) student learning and comprehension; (4) purposes; (5) curriculum; and (6) instructional techniques. The improved categories of TPK by Meijer et al. (2002) were: (1) subject matter; (2) individual students; (3) students in general; (4) student learning and understanding; (5) goals; (6) the curriculum; (7) instructional techniques; (8) the particular class; (9) teacher-student interaction; and (10) process regulation.

van Dreil et al. (2001) reviewed the studies of several scholars and matched the conceptualizations of pedagogical content knowledge in these studies, which resulted in a list of categories that could be distinguished within the practical knowledge: (1) subject matter; (2) general pedagogy; (3) student learning and conceptions; (4) purposes; (5) curriculum and media; (6) representations and strategies; and (7) context.

Q. LI's (2010) classification comparatively devoted to the classroom context and teachers' articulation of thought: (1) general pedagogical knowledge; (2) knowledge of context; (3) pedagogical content knowledge; (4) knowledge of learners; (5) subject content knowledge; (6) personal beliefs on subject education; (7) reflection in class; (8) affect; (9) knowledge of self; (10) personal beliefs on people education; and (11) imitation.

Though there are different classifications, the components of TPK should at least embody the dynamic features of teaching. Through substantial classroom observations, in-depth interviews, and case-studies for many years, CHEN (2009a) stated that TPK possessed at least four essential elements. They were: (1) subject: the possessor of TPK is teacher, not researchers; (2) problem-based situation: teachers should be faced with a confusing problem; (3) reflection-in-action: teachers have to find a way to solve the problem and from which the reconstructed information they draw will further guide their teaching actions in the future; and (4) beliefs: the knowledge teacher get from experiences can be changed into beliefs after having been validated in practice and finally is proved to be true. It can be seen what problems teachers have in class, how they cope with them spontaneously and how their reflection-in-action informs their previous belief system. Apart from the sheer teacher-student-curriculum interaction, teaching involves teachers' aesthetic, moral, and emotional states of mind.

\section{The Nature of TPK}

The practical knowledge that teachers construct in teaching practice is the conjunct product of personal life experience, teaching practice, and the teaching environment. TPK is a notion that has been crafted by teachers in their teaching practice to suit particular work settings. It is therefore personalized, context-specific, and action-guided. It has emerged as the valued prize of countless hours of practice, trial and error, and reflection. It does offer teachers guidelines as to what will probably be most effective in particular teaching contexts. The most important features of TPK are described below:

(1) It is personal. Teachers' biographic histories and subject background (research-generated knowledge), beliefs and values play an important role in TPK (Saka, 1995);

(2) It is contextual. It is adapted to classroom situation, which includes the concerns about students, the course books and other learning materials, the curriculum, the school culture, the national education standards; 
(3) It is action-oriented. It is the wisdom of teachers on the basis of their experiences, which they can use in solving problems in their own classroom teaching practice (Carter, 1990; Beijaard \& Verloop, 1996);

(4) It is tacit. Teachers are not used to articulating their practical knowledge. They feel more natural in a “doing” environment than in a "knowing” environment (Clandinin, 1986; Eraut, 1994);

(5) It is reflective and affective. Reflection happens anytime in class. The contents of reflection varies a lot from the effectiveness of happened tasks to the review of future plans, from pondering on the problems of failures to predicting what will happen. At the same time, teachers reveal the feelings and emotions naturally in class, such as confused, frustrated, delighted, shocked, relieved, and nervous ones;

And (6) It is open and developing. TPK is not stable but evolving. When new philosophies start shaping during classroom teaching, some old ones are seen in a new light.

\section{Ways to Elicit TPK}

Research on TPK has also resulted in a range of creative methods to elicit this type of knowledge. Many researchers of TPK embed their studies in a narrative approach. The underlying assumption is that narratives are not only crucial for providing insight into what teachers think and do, they also help teachers to make sense of what they think and do. Narrative research can be seen as a means of understanding teachers' culture from within (Cortazzi, 1993), by making use of personal materials such as life stories, conversations, personal writings, metaphor, journals, and story-line methods (Connelly \& Clandinin, 1990; Elbaz, 1997; D. LI, 2005; Carter, 1990; Gergen, 1988). However, it should be cautious to apply them as such methods may lead to a collection of idiosyncratic teacher narratives, without any reference to scientific study (Tom \& Valli, 1990). We agree with van Dreil et al. (2001) that it is problematic if researchers merely let teachers talk without interpreting their stories in terms of similarities and differences between them.

Recently, to investigate teacher knowledge in use, a lot of researchers use a multiple-method triangulation method (combined with stimulated verbal recalls) to triangulate the data. Stimulated verbal recall is a method in which teachers watch a videotape of themselves teaching and simultaneously report on the thoughts they have while teaching. The instrument has its origin in studies by Bloom (1953). This instrument allows teachers to retrieve their thinking in a vivid way. Although thinking-aloud technique is ideal to capture a teacher's thinking, it is unworkable in reality as it would interfere with lessons when he or she is teaching. Using this method of stimulated verbal recalls, however, can aid the teachers in the reliving of interactive thoughts. The stimulated recall interview "can be used to make much of teachers' tacit thinking explicit and to elicit cognitions underlying their observable actions” (Meijer, 2010, p. 647). Q. LI (2010) adopted the method of teachers' stimulated verbal recalls which was proved to be resourceful in eliciting cognitions (Marland, Dashwood, \& Son, 2004), together with in-depth interviews and observations to triangulate the data. Such an approach seeks to understand teaching in its own terms and in ways in which it is understood by teachers. Meijer et al. (2002) used three instruments: semi-structured interview, stimulated recall interview, and concept mapping to elicit TPK. Others included designs of Peterson, Fennema, Carpenter, and Loef's (1989) Likert-type questionnaires, in combination with interviews and experimental tasks, and of Smith and Neale's (1989) structured interviews, combined with teachers' logs, transcripts of actual lessons, and stimulated recalls.

Although we are not sure whether these instruments can completely access TPK, we have confidence in 
saying that with both the theoretical and methodological progress of other fields, such as psychology, general education, the SLE researchers will get closer and closer to TPK.

\section{Two Lines of Research}

Though teachers' experience that constitutes their everyday work claims priority in all the studies, literature review reveals that researchers vary in where and how to capture experiences to understand TPK resting on different theoretical and methodological foundation. Generally there are two lines of research in the academic research field of TPK. The representatives of the first line of research which are influential in the last decades of the 20th century are Elbaz, Clandinin, and Connelly, and the representatives of the second one are Meijer and Verloop and some other researchers in the UK, the US, and Canada. In China, literature review shows that Chinese researchers are kind of affected by both of these two lines.

In the first line of research, Elbaz (1983) was the earliest in systematically studying TPK. Based on her two-year study of a very experienced high school teacher "Sarah", Elbaz applied "practical knowledge” to refer to a special kind of knowledge that teacher possessed because this term "focuses attention on the action and decision-oriented nature of the teacher's situation, and construes Sarah's knowledge as a function, in part, of her response to that situation... and this knowledge encompasses first-hand experience of students' learning styles, interests, needs, strengths, and difficulties, and a repertoire of instructional techniques and classroom management skills” (Elbaz, 1983, p. 5). She found that what Sarah knew was not theory, or empirical propositions, but how to carry out instructional tasks, resolve conflicts, adjudicate competing considerations, and connect aspirations to plans and then to instructional performance. In addition, such practical knowledge was represented in practice in three ways: as rules of practice, which were "brief, clearly formulated statements of what to do or how to do it in a particular situation” (Elbaz, 1983, p. 132); as practical principles, which were "more inclusive and less explicit formulations in which the teachers' purpose... are more clearly evident”; as images, which were defined as:

A brief, descriptive, and sometimes metaphoric statement which seems to capture some essential aspect of Sarah's perception of herself, her teaching, her situation in the classroom or her subject matter, and which serves to organize her knowledge in the relevant areas. (Elbaz, 1983, p. 137)

Connelly and Clandinin's work emphasized the epistemological concept of "teachers' personal knowledge”. They contributed a lot in improving the academic status of the research on teachers' experiences which had been ignored for a long time. "The social sciences are founded on the study of experience. Experience is therefore, the starting point and key term for all social inquiry experience" (Clandinin \& Connelly, 1994, p. 415). And personal practical knowledge was designed "to capture the idea of experiences in way that allows us to talk about teachers as knowledgeable and knowing persons”(Connelly, Clandinin, \& HE, 1997). For them, knowledge was derived from personal experience and was not something objective and independent of the teacher that was to be learned and transmitted but, rather, was the sum total of the teacher's experiences. Personal practical knowledge was:

A term designed to capture the idea of experience in a way that allows us to talk about teachers as knowledgeable and knowing persons. ...It is, for any one teacher, a particular way of reconstructing the past and the intentions of the future to deal with the exigencies of a present situation. (Connelly \& Clandinin, 1988, p. 25) 
Connelly and Clandinin's program group (1988, 1990) collected field notes, research interviews, conversations, journals, autobiographical writings, teacher stories, family stories, photographs, memory boxes, other personal artifacts, annals and chronicles, and letters. And then they developed conceptual terms such as image, rules, practical principles, personal philosophy, metaphor, cycles, rhythms, and narrative unities to describe TPK. Scholars in China were greatly enlightened by Connelly and Clandinin's way of study. Researchers like JU (2003), L. LI and SUN (2010), and WANG (2011) adopted this narrative method.

However, drawing insights from Polkinghorne (1988) and Maclntyre (1984), Connelly and Clandinin's use of the techniques of narrative story unity and the notions of it to study teacher knowledge was controversial. Apart from the difficulties in applying precisely these conceptions, Fenstermarcher (1994) criticized that "it is possible for a research program to be so heavily enmeshed in theory and conceptualization that it risks being blurred by its own abstractions" (p. 14).

It becomes clear that Elbaz, Connelly, and Clandinin all focused more on the biographical histories of teachers, or rather, the personal and "out-of classroom” landscape while neglected the "in-classroom” landscape. TPK is largely related to what teachers have already known. Teachers' personal beliefs, principles, and values are explored fully, however, how their knowing functions on their dynamic daily practices is not well probed. Calderhead (1996) stated in his review that we had gained much insight into teachers' knowledge and beliefs, but the relationship of their knowledge and beliefs with their practice of teaching was still unclear. Meijer (2010) also criticized that "many established theories about teaching do not seem to correspond to what teachers know and do in practice” (p. 642). A great number of scholars (Bailey \& Nunan, 1995; Richards, 1996) also stressed the need to listen to teachers' voices in understanding classroom practice. Likewise, the long period of separation between teachers' knowledge about theories and their classroom practice may explain the reason why the teacher-preparation programs are still not very successful in China (Y. WU, 2008; Z. WU, 2005).

The second line of research stated that practical knowledge was bounded by the situation or context in which it arose. It "cannot be examined without reference to what actually goes on in the classroom” (Borg, 1999, p. 161). The research aimed at understanding what teachers knew in the practices-based situation. These studies effectively defined practical knowledge in terms of both thought and action. Meijer et al. (1999) tended to find out what the contents of TPK are and which is shared among teachers. In their study in 1999, the dynamic in-class teaching practices were not given full attention yet. They interviewed and collected concept maps from 13 experienced language teachers who taught reading comprehension to 16-18-year-old students. Taking into account of personal characteristics, frequency and nature of reflection, prior education, years of experience, the language taught, and the school context, they classified TPK into six domains from the collected data. While in Meijer et al.'s (2002) study, grounding their work in the "working memory" and "long-memory" theory of Baddeley and Hitch (1974) and Anderson (1980), they stated that TPK contained two elements: One was teacher's knowledge (here it was referred to as the traditional content knowledge) and beliefs which were relatively stable and stored in long-term memory; the other was their interactive cognition which was essentially dynamic and was found in a person's working memory. Compared with their previous study, the subject and the two instruments were still the same but the stimulated recall interview was added in which teachers explicated what they were thinking while teaching in response to the videotape of a lesson they had just given in order to examine teachers' interactive cognitions. Results showed tremendous differences and 10 categories were 
redefined. Q. LI's (2010) study of novice English language teachers' TPK also contributed to detecting the situational elements of TPK: reflection in class, affect, self-awareness, and imitation.

Apart from these, a number of excellent studies were grounded in the knowing-in-action frame. Erickson and MacKinnon (1991), and Grimmett and MacKinnon (1992) showed a greater interest in how knowledge arises in the context of action as well as the consequences of this knowledge for practice than in the description of this knowledge through narrative or story (hence the greater use of video tape to record the actions of teachers). Burns (1992) examined the relationship between six ESL (English as a second language) teachers' personalized theories and practices and confirmed the importance of raising teachers' consciousness of the personalized theories which informed their practice. Along a similar line of research, a study by Golombek (1998) showed that the personal practical knowledge of two in-service ESL teachers informed their practice by filtering experience and giving physical form to their practice. This reiterated the importance of understanding the role of personal practical knowledge, as it was believed that this underlied the classroom practice of a teacher to a considerable extent (Clandinin, 1986; Connelly \& Clandinin, 1988). Breen, Hird, Milton, Oliver, and Thwaite (2001) examined the relationship between actions and rationale of 18 experienced ESL teachers in Australia and identified the ways in which teachers constructed pedagogy through their principles of teaching. In a more recent study, Tsang (2004) investigated the role of teachers' personal practical knowledge in interactive decision making for three pre-service non-native ESL teachers and found that the teachers had limited access to their personal practical knowledge, which however played a part in informing post-active decisions. JIANG and HAO (2010) compared the teaching process of four TCFL (teaching Chinese as a foreign language) teachers and found that language management, knowledge about the students, notice of students' responses and behaviors, decision-making, checking on teaching process, progress review, and beliefs were reported more frequently than other pedagogical thoughts. They also noticed that the categories of language management, self-criticism, and planned action were reported more frequently by novice teachers than by experienced teachers, while those of beliefs, knowledge about the students and past experience were less frequently reported by the novice than by the experienced. After a longitudinal study about a college English novice teacher, collecting data from the stimulus reports and teaching journals, Q. LI et al. (2013) found that at the end of one year's teaching, though many new principles were reported, no new categories of TPK were formed.

It can be seen that the two lines of research have different assumptions, use different approaches and methods and therefore come to different outcomes. The first line of research aims to describe the knowledge teachers already have through biological histories and thoughts in isolation from action while the other intends to know what knowledge teachers hold in action and how this knowledge is reconstructed later. In the first line of research, teacher knowledge is believed to be inferred from narratives and stories, while in the second, TPK is believed to be found in the act of teaching. However, both of the two lines of research emphasize the importance of the epistemological concept of TPK.

\section{Conclusions}

As we review the research of TPK, it is suggested that studies in this field still rest on the conceptual issues. Research in the past lingers too much on the incomplete definition of TPK and therefore inappropriate instruments to elicit TPK. Though the dynamic interactive practical knowledge is emphasized, it is still skeptical 
about the effective description of TPK. Furthermore, little effort is exerted on the reconstruction of TPK. And the most important challenge for TPK research is not simply one of showing us what teachers know but what they can make use of their knowledge in a beneficial way to facilitate students' learning. What is more important, more empirical studies should be done to explore EFL (English as a foreign language) TPK in view of the educational reform in China.

\section{References}

Anderson, J. R. (1980). Cognitive psychology and its implications. San Francisco: Freeman.

Baddeley, A. D., \& Hitch, G. (1974). Working memory. The Psychology of Learning and Motivation, 8, 47-89.

Bailey, K., \& Nunan, D. (Eds.). (1995). Voices from the language classroom. New York: Cambridge University Press.

Bartels, N. (2005). Applied linguistics and language teacher education. New York: Sprinster.

Beijaard, D., \& Verloop, N. (1996). Assessing teachers’ practical knowledge. Studies in Educational Evaluation, 22(3), $275-286$.

Black, A. L., \& Hailliwel, G. (2000). Accessing practical knowledge: How? why?. Teaching and Teacher Education, 16, 103-115.

Bloom, B. S. (1953). Thought processes in lectures and discussions. Journal of General Education, 7, 160-169.

Borg, S. (1999). Teachers' theories in grammar teaching. ELT Journal, 53(3), 157-167.

Breen, M. P., Hird, B., Milton, M., Oliver, R., \& Thwaite, A. (2001). Making sense of language teaching: Teachers’ principles and classroom practices. Applied Linguistics, 22(4), 470-501.

Burns, A. (1992). Teacher beliefs and their influence on classroom practice. Prospect, 7(3), 56-66.

Calderhead, J. (1990). Conceptualising and evaluating teachers' professional learning. European Journal of Teacher Education, 13(3), 153-159.

Calderhead, J. (1996). Teachers: Beliefs and knowledge. In D. C. Berliner \& R. C. Calfee (Eds.), Handbook of educational psychology (pp. 709-725). New York: Simon \& Schuster MacMillan.

Carter, K. (1990). Teachers' knowledge and learning to teach. In W. R. Houston (Ed.), Handbook of research on teacher education (pp. 291-310). New York: Macmillan.

CHEN, X. (2003). Practical knowledge: The knowledge base of teacher professional development. Peking University Education Review, 1, 104-112.

CHEN, X. (2009a). On the constituting components of teachers' practical knowledge. Educational Research, 10, 66-73.

CHEN, X. (2009b). Epistemological foundation for research on teachers' practical knowledge. Journal of Educational Studies, 5(2), 47-56.

Clandinin, D. J. (1986). Classroom practice: Teacher images in action. London: Falmer Press.

Clandinin, D. J., \& Connelly, F. M. (1987). Teachers' personal knowledge: What counts as “personal” in studies of the personal. Curriculum Studies, 19(6), 487-500.

Clandinin, D. J., \& Connelly, F. M. (1994). Personal experience methods. In N. Denzin \& Y. Lincoln (Eds.), Handbook of qualitative research (pp. 413-427). London: Sage Publications Ltd..

Connelly, F. M., \& Clandinin, D. J. (1985). Personal practical knowledge and the modes of knowing: Relevance for teaching and learning. In E. Eisner (Eds.), Learning and teaching the ways of knowing (pp. 174-198). Eighty-fourth Yearbook of the National Society for the Study of Education. Chicago: University of Chicago Press.

Connelly, F. M., \& Clandinin, D. J. (1988). Teachers as curriculum planners. New York: Teachers College Press.

Connelly, F. M., \& Clandinin, D. J. (1990). Stories of experience and narrative inquiry. Educational Researcher, 19(5), 2-14.

Connelly, F. M., Clandinin, D. J., \& HE, M. F. (1997). Teachers' personal practical knowledge on the professional knowledge landscape. Teaching and Teacher Education, 13(7), 665-674.

Cortazzi, M. (1993). Narrative analysis. Washington: Falmer Press.

Duffee, L., \& Aikenhead, G. (1992). Curriculum change, student evaluation, and teacher practical knowledge. Science Education, 76, 493-506.

Elbaz, F. (1983). Teacher thinking: A study of practical knowledge. London: Croom Helm.

Elbaz, F. (1997). Narrative research: Political issues and implications. Teaching and Teacher Education, 13, 75-83.

Eraut, M. (1994). Developing professional knowledge and competence. London: Falmer Press.

Erickson, G. L., \& MacKinnon, A. M. (1991). Seeing classrooms in new ways: On becoming a science teacher. In D. A. Schön (Ed.), The reflective turn: Case studies in and on educational practice (pp. 15-36). New York: Teachers College Press. 
Fenstermarcher, G. D. (1994). The knower and the known: The nature of knowledge in research on teaching. Review of Research on Teaching, 20, 1-54.

Gergen, M. M. (1988). Narrative structures in social explanation. In C. Antaki (Ed.), Analysing social explanation (pp. 94-112). London: Sage.

Ghaith, G., \& Yaghi, H. (1997). Relationship among experience, teacher efficacy, and attitudes toward the implementation of instructional innovation. Teaching and Teacher Education, 13(4), 451-458.

Golombek, P. R. (1998). A study of language teachers’ personal practical knowledge. TESOL Quarterly, 32(3), 447-464.

Grimmett, P. P., \& MacKinnon, A. M. (1992). Craft knowledge and the education of teachers. Review of Research in Education, 18, 385-456.

JIANG, X., \& HAO, L. (2010). A case study of the practical knowledge of teaching Chinese as foreign language teachers. Chinese Teaching in the World, 3, 394-405.

JIANG, X., \& HAO, L. (2011). The practical knowledge of novice and experienced teachers of Chinese as a second language. Language Teaching and Research, 2, 1-8.

Johnson, K. E. (1999). Understanding language teaching: Reasoning in action. Boston: Heinle and Heinle.

JU, Y. (2003). Teacher education and the reconstruction of teachers’ personal knowledge. Education Exploration, 20(3), 92-94.

Kagan, D. M. (1990). Ways of evaluating teacher cognition: Inferences concerning the Goldilocks principle. Review of Educational Research, 60, 419-469.

Kettle, B., \& Sellars, N. (1996). The development of student teachers’ practical theory of teaching. Teaching and Teacher Education, 12(1), $1-24$.

Leinhardt, G. (1988). Situated knowledge and expertise in teaching. In J. Calderhead (Ed.), Teachers’ professional learning (pp. 146-168). London: Falmer.

Leung, C. (2009). Second language teacher professionalism—Whose agenda?. In A. Burns \& J. C. Richards (Eds.), The Cambridge guide to second language teacher education. Cambridge: Cambridge University Press.

LI, D. (2005). The reconstruction of novice teachers' practical knowledge-Analyzing from teachers' life history. Contemporary Educational Science, 12, 26-30.

LI, L., \& SUN, H. (2010). The reconstruction process of teachers' practical knowledge: A case study. Global Education, 39(3), 63-71.

LI, Q. (2010). An empirical study of the categories and reconstruction of high school novice English teachers' practical knowledge in classroom teaching (Unpublished M.A. thesis, Southwest University, Chongqing).

LI, Q., JIANG, Y., \& LENG, P. (2013). The reconstruction process of college novice English teachers. English Teachers, 3, 12-19.

Maclntyre, A. (1984). After virture: A study in moral theory. Notre Dame: University of Notre Dame Press.

Marland, F. M. P., Dashwood, A., \& Son, J. B. (2004). Teaching a foreign language: One teacher's practical theory. Teaching and Teacher Education, 20(3), 291-311.

Meijer, P. C. (2010). Experienced teachers' craft knowledge. Teacher education-preservice: The knowledge base (pp. 642-649). Amsterdam: ElsevierAcademic Press.

Meijer, P. C., Verloop, N., \& Beijaard, D. (1999). Exploring language teachers' practical knowledge about teaching reading comprehension. Teaching and Teacher Education, 15, 59-84.

Meijer, P. C., Verloop, N., \& Beijaard, D. (2002). Multi-method triangulation in a qualitative study on teachers' practical knowledge: An attempt to increase internal validity. Quality \& Quantity, 36, 145-167.

Munby, H. (1983). A qualitative study of teachers' beliefs and principles. The Annual Meeting of the American Educational Research Association. Montreal.

Olson, J. (1981). Teacher influence in the classroom. Instructional Science, 10, 259-275.

Peterson, P. L., Fennema, E., Carpenter, T. P., \& Loef, M. (1989). Teachers’ pedagogical content beliefs in mathematics. Cognition and Instruction, 6, 1-40.

Polkinghorne, D. E. (1988). Narrative knowing and the human sciences. Albany, New York: State University of New York Press.

Richards, J. C. (1996). Teachers’ maxims in language teaching. TESOL Quarterly, 30(2), 281-296.

Richards, J. C., \& Lockhart, C. (1996). Reflective teaching in second language classrooms. Cambridge: Cambridge University Press.

Richardson, V. (1996). The role of attitudes and beliefs in learning to teach. In J. Sikula (Ed.), Handbook of research on teacher education (pp. 102-119). New York: MacMillan. 
Saka, A. R. (1995). The teaching and learning of English as a foreign language: A constructivist approach (Unpublished Ph.D. dissertation, University of Reading, Reading).

Sendan, F. (1995). Patterns of development in ELT student teachers’ personal theories: A constructive approach (Unpublished Ph.D. dissertation, University of Reading, Reading).

Sendan, F., \& Roberts, J. (1998). Orhan: A case study in the development of a student teacher's personal theories. Teachers and Teaching: Theory and Practice, 4(2), 229-244.

Shulman, L. S. (1987). Knowledge and teaching: Foundations of the new reform. Harvard Educational Review, 57(1), 1-22.

Smith, D. C., \& Neale, D. C. (1989). The construction of subject matter knowledge in primary science teaching. Teaching and Teacher Education, 5, 1-20.

Tom, A. R., \& Valli, L. (1990). Professional knowledge for teachers. In W. R. Houston (Ed.), Handbook of research on teacher education (pp. 372-392). New York: Macmillan.

Tsang, W. K. (2004). Teachers' practical knowledge and interactive decisions. Language Teaching Research, 8(2), 163-198.

Tsui, A. B. M. (2003). Understanding expertise in teaching. Cambridge: Cambridge University Press.

van Dreil, J. H., Beijarrd, V. D., \& Verloop, N. (2001). Professional development and reform in science teacher education: The role of teachers' practical knowledge. Journal of Research in Science Teaching, 38(2), 137-158.

van Manen, M. (2008). Pedagogical sensitivity and teachers' practical knowing-in-action. Peking University Education Review, $6(1), 2-20$.

Wallace, J., \& Louden, W. (1992). Science teaching and teachers' knowledge: Prospects for reform of elementary classrooms. Science Education, 76, 507-521.

WANG, Y. (2011). On good EFL teachers' practical knowledge: A case study. Foreign Language Learning Theory and Practice, 1 , 68-75.

WU, Y. (Ed.). (2008). Research on Chinese university English teacher education and development. Beijing: Foreign Language Teaching and Research Press.

WU, Z. (2005). Teachers' knowing in curriculum change: A critical discourse study of language teaching. Beijing: Foreign Language Teaching and Research Press.

ZHANG, L. (2011). Research on the teachers' practical knowledge in the classroom teaching horizon (Unpublished Ph.D. dissertation, Northeast Normal University, Changchun).

ZHANG, M. (2008). A case study of teachers' practical knowledge (Unpublished M.A. thesis, Shandong Normal University, Jinan). 